Original Research

\title{
Deep Breathing Relaxation for Decreasing Blood Pressure in People with Hypertension
}

\section{Rahmatul Fitriyah, Gratsia Victoria Fernandez, Wahyu Sukma Samudera, Hidayat Arifin and Shenda Maulina Wulandari}

Faculty of Nursing, Universitas Airlangga, Surabaya, Indonesia

\begin{abstract}
Introduction: Various non-pharmacological therapies can be used to reduce blood pressure. One of them is deep breathing relaxation. This study aimed to know the influence of deep breath relaxation to decrease the blood pressure of people with hypertension.

Methods: The design of this study was an Pre-Experimental One Group Pretest-Post-test design which covered 30 respondents as the sample. They fulfilled the inclusion criteria and were chosen through purposive sampling. The independent variable in this study was deep breath relaxation and the dependent variable was blood pressure. The data collection technique was using the observation sheet of blood pressure measurement. Data were analyzed using the paired test.
\end{abstract}

Results: The findings of this study majority there were decrease blood pressure after deep breath. Before doing the breath relaxation exercise, most of the respondents were hypertension level 1 . Nonetheless, after the deep breath relaxation had been executed, most found that their blood pressure decreased although several respondents were at hypertension level 2 with stable blood pressure.

Conclusion: There were differences in the blood pressure patients with hypertension before and after the deep breath relaxation. There were several points which influenced the decrease in blood pressure after implementing the deep breath relaxation such as stress, cigarettes etc.

\section{ARTICLE HISTORY}

Received: December 26, 2019

Accepted: December 31, 2019

\section{KEYWORDS}

deep breathing; blood pressure; hypertension

\section{CONTACT}

Rahmatul Fitriyah

$\triangle$ rahmatul.fitriyah-

2018@fkp.unair.ac.id

$\doteq$ Faculty of Nursing, Universitas

Airlangga, Surabaya, Indonesia

Cite this as: Fitriyah,, R, Gratsia Victoria Fernandez, G. V., Samudera, W. S., Arifin, H \& Wulandari, S. M. (2019). Deep Breathing Relaxation for Decreasing Blood Pressure in People with Hypertension. Jurnal Ners, 14(3si), 141-145. doi:http://dx.doi.org/10.20473/jn.v14i3(si).16945

\section{INTRODUCTION}

Hypertension is a persistent elevation of the systolic blood pressure at a level of $>140 \mathrm{mmHg}$ and a diastolic blood pressure at a level of $>90 \mathrm{mmHg}$. Hypertension must be controlled because it is related to myocardial infarction, stroke, renal failure and it is the main cause of death in United States(Armstrong, 2014)(NICE, 2011). Cardiovascular disease is one of the main causes of death in the world. The development of cardiovascular disease is caused by the accompanying risk factors that are not immediately handled(Du et al., 2016).

Data from the WHO in 2019 showed that raised blood pressure caused 7,5 million deaths or about $12,8 \%$ of the total deaths in the world. The number of people with uncontrolled hypertension has risen from 600 million in 1980 to nearly 1 billion in
2008(WHO (World Health Organization), 2019). In 2010, there was an estimated 1,39 billion people with hypertension (Mills, 2016). The prevalence of raised blood pressure was highest in Africa, as it was $46 \%$ for both genders. The lowest prevalence of raised blood pressure was in America, at 35\%. In America, men had a higher prevalence (39\%) than women (32\%)(WHO (World Health Organization), 2019).

The percentage of people with hypertension in Indonesia had risen from $25,8 \%$ in 2013 to $34,1 \%$ in 2018. The highest prevalence of hypertension in Indonesia was in North Sulawesi at about 13,2\% and the lowest prevalence was in Papua (RI, 2018).

In some age groups, the risk of cardiovascular disease increases twice for each increment of 20/10 $\mathrm{mmHg}$ of blood pressure. Besides that, the complications of raised blood pressure include heart failure, peripheral vascular disease, renal 
impairment, retinal hemorrhage and visual impairment(Park \& Han, 2017). The lifestyle of the patients with hypertension must be controlled, for example, including a good diet (high fiber, low fat), a weight control program, physical exercise, drug therapy and reducing their psychological stress [1](Park \& Han, 2017)(Staffileno, Tangney, \& Fogg, 2018). Uncontrolled hypertension can cause serious problems for their overall health(Park \& Han, 2017).

It is important for the patients with hypertension to control their stress levels for the sake of their blood pressure management(Park \& Han, 2017). One of the non-pharmacological interventions for controlling blood pressure approved by FDA is deep breath relaxation (Mahtani, Beinortas, Bauza, \& Nunan, 2016)

In this study, the researchers wanted to know the influence of deep breath relaxation on decreasing the blood pressure of people with hypertension.

\section{MATERIALS AND METHODS}

The design of this study was PraEksperimental with a one group pre- post-test design. There was one group of people with hypertension. Before and after implementing the deep breath relaxation, the respondents had their blood pressure measured with a standardized sphygmomanometer. The aim of this research design was to compare the blood pressure measurement before and after implementing the deep breath relaxation.

The population in this research was all of the patients with hypertension in the Citizen's Association 05 of Sawunggaling village, sub-district Wonokromo, Surabaya. This research was conduct on April 2nd 2015 with 109 individuals. The inclusion criteria in this research were 1) patients with hypertension diagnosed by a physician, 2) patients with hypertension aged 30 - 59 years old and 3) those who had given informed consent for the research. There were 30 respondents who fulfilled the inclusion criteria for the sample in this research.

The independent variable in this study was deep breathing relaxation. The dependent variable was blood pressure. This study used a sphygmomanometer, stethoscope and observation sheet with the following guidance: 1) Normotension: SBP (120-139) DBP (80-89), 2) Hypertension stage 1: SBP (140-159) DBP (90-99) and 3) Hypertension stage 2: SBP $(\geq 160)$ DBP $(\geq 100)$. This standard is based on that of Joint National Committee 8 (JNC 8).

The patient's blood pressure was measured by the researcher before implementing the relaxation. After that, the researcher accompanied them and gave the patients the instructions for the deep breath relaxation for about 15 minutes. After the procedure, their blood pressure was measured again to determine the results of the procedure.

The data was analyzed using IBM SPSS Statistic 16 with a paired t-test. This research was carried out in collaboration with Jagir primary health service. This research passed the ethical review from the Institute of Health Science Katolik St. Vincentius A Paulo Surabaya, certificate No. 072/7860/436.6.3/2015.

\section{RESULTS}

Table 1. Characteristics of the respondents who were patients with hypertension $(n=30)$

\begin{tabular}{|c|c|c|}
\hline \multirow[b]{2}{*}{ Characteristic } & \multicolumn{2}{|c|}{ Result } \\
\hline & $\mathbf{n}$ & $\%$ \\
\hline \multicolumn{3}{|l|}{ Age } \\
\hline Adult $(30-44)$ & 4 & 13 \\
\hline Elderly (45-59) & 26 & 87 \\
\hline \multicolumn{3}{|l|}{ Sex } \\
\hline Male & 10 & 33 \\
\hline Female & 20 & 67 \\
\hline \multicolumn{3}{|c|}{ Family with hypertension } \\
\hline Yes & 19 & 63 \\
\hline No & 11 & 37 \\
\hline \multicolumn{3}{|l|}{ Like salty food } \\
\hline Yes & 20 & 67 \\
\hline No & 10 & 33 \\
\hline \multicolumn{3}{|l|}{ Smoker } \\
\hline Yes & 8 & 27 \\
\hline No & 22 & 73 \\
\hline \multicolumn{3}{|l|}{ Kind of tobacco } \\
\hline Cigarettes & 5 & 63 \\
\hline Filter & 3 & 37 \\
\hline \multicolumn{3}{|c|}{ Adherence to medicine } \\
\hline Yes & 23 & 77 \\
\hline No & 7 & 23 \\
\hline \multicolumn{3}{|l|}{ Have great problem } \\
\hline Yes & 5 & 17 \\
\hline No & 25 & 83 \\
\hline \multicolumn{3}{|l|}{ Physical exercise } \\
\hline$>2 \mathrm{x} /$ week & 7 & 23 \\
\hline$\leq 2 \mathrm{x} /$ week & 18 & 60 \\
\hline Seldom & 5 & 17 \\
\hline \multicolumn{3}{|c|}{ Alcohol consumption } \\
\hline Yes & 0 & 0 \\
\hline No & 30 & 100 \\
\hline
\end{tabular}

Table 2. Differences in blood pressure before and after the Deep Breathing Relaxation $(n=30)$

\begin{tabular}{lcccc}
\hline $\begin{array}{c}\text { Differences of Blood } \\
\text { Pressure before and } \\
\text { after DBR }\end{array}$ & \multicolumn{2}{c}{ Before } & \multicolumn{2}{c}{ After } \\
\cline { 2 - 5 } & $\mathbf{n}$ & $\mathbf{\%}$ & $\mathbf{n}$ & $\mathbf{\%}$ \\
\hline HT St 1 & 22 & 73 & 14 & 47 \\
HT St 2 & 8 & 27 & 6 & 20 \\
Normal tension & 0 & 0 & 10 & 33 \\
Total & 30 & 100 & 30 & 100 \\
\hline
\end{tabular}

The characteristics of the respondents as seen in Table 1 show that most of the respondents are the elderly and female. Most of them had a family history of hypertension, they often ate salty food, were a nonsmoker, took their medicine regularly, did not consume alcohol and were not stressed. For physical exercise, they did it at least twice a week.

Before implementing deep breathing relaxation, none of the respondents had a normal blood pressure measurement. After implementing DBR, 33\% of the respondents had normal blood pressure. The respondents with hypertension in stage 1 made up $73 \%$ before given DBR and this decreased to $47 \%$ after given DBR. The respondents with hypertension 
in stage 2 made up $27 \%$ before implementing DBR and this decreased to $20 \%$ after implementing DBR.

\section{DISCUSSION}

Based on this study, before implementing Deep Breathing Relaxation (DBR), most of the respondents had hypertension stage 1 . In terms of age, most of the respondents were elderly. The incidence of hypertension increases with age (Triyanto, 2014). This is caused by natural changes in the body that affects the heart, blood vessels and hormones.

The structural and functional changes especially occur in the peripheral vascular system. These changes include atherosclerosis, a loss of connective tissue elasticity and a decrease in the relaxation of the vascular smooth muscles, which in turn decreases blood vessel distention and stretching ability, so the consequence is that the large aorta and arteries diminish in their ability to accommodate the volume of blood pumped by the heart, resulting in a decreased cardiac output and increased peripheral resistance. This causes an increase in blood pressure. Uncontrolled hypertension could increase the risk of heart failure, coronary heart disease and major cardiovascular disease(Ettehad D, 2016).

Besides that, there were a minority of respondents of a younger age who were suffering from hypertension. In terms of the demographic data, they had a family history of hypertension and they often ate salty food. The consumption of salty food can increase the blood pressure because salty food contains sodium.

Deep breathing relaxation consisted of breathing with slow breaths to a point of maximal inhalation before slowly exhaling. This could reduce the pain intensity, improve lung ventilation and increase blood oxygenation. Slow deep breathing training is acceptable for older people (Sangthong B, 2016).

Pharmacological treatment should be given when the systolic pressure is $\geq 150 \mathrm{mmHg}$ and when the diastolic pressure is $\geq 90 \mathrm{mmHg}$ and the target is $140 / 90 \mathrm{mmHg}$. Slow deep breathing also effectively reduced the blood pressure in terms of the essential and isolated systolic hypertension, even in patients with conventional pharmacological treatments (Sangthong B, 2016)(Jones CU, 2010).

In several studies there have been shown to be non-pharmacologic treatments that can decrease blood pressure such as yoga, meditation, etc. Slow and deep breathing is important thing in yoga and meditation (Bai et al., 2015)(Posadzki, Cramer, Kuzdzal, Lee, \& Ernst, 2014). Slow breathing could reduce the systolic blood pressure (Elliot W.J, 2004). Yoga could reduce the sistolic blood pressure more significantly than meditation, especially in the elderly respondents ( $>60$ years) (Park \& Han, 2017).

The results of study confirmed that 8 weeks of slow loaded breathing reduces the SBP and DBP by approximately 20 and $10 \mathrm{~mm} \mathrm{Hg,} \mathrm{MAP} \mathrm{by} 15 \mathrm{~mm} \mathrm{Hg}$ and HR by $12 \mathrm{bpm}$. The data also showed that the load (25\% MIP) was increased significantly in relation to the respiratory muscle strength, lung capacity, chest and abdominal expansion and arm exercise endurance(Ublosakka-Jones, Tongdee, Pachirat, \& Jones, 2018).

Based on this study, most of the respondents had decreased blood pressure after practicing the deep breath relaxation, even to the point of becoming normotension. This is in line with the research in other countries indicating that slow and deep breathing could their decrease blood pressure.

The relaxation process could inhibit the autonomic nervous system and central nervous system, in addition to increasing the parasympathetic nervous system. The parasympathetic nervous system controls the digestive system, respiratory system and heart rate during the rest period. The autonomic nervous system influences the blood pressure through the arterial baroreceptors and pulmonary strech receptors (Joseph C.N, 2005). Deep breathing stimulates the stretch receptors, increases the vagal tone, decreases the sympathetic activity and the result is a decrease in blood pressure (Misra et al., 2018).

Deep breathing could stimulate the stretch receptors, increase vagal tone and decreased sympathetic activity. This results in a decrease in blood pressure and heart rate[10](Wan R, 2014). Low breathing activates the Hering-Breuer reflex to improve baroreflex sensitivity and the result was a decreased heart rate and blood pressure(Joseph C.N, 2005).

FDA recommends that breathing exercises should be an adjunct anti-hypertensive treatment that can be practiced at home, as published in 2002. There were several devices like a control box, headphones and a respiratory rate monitor in the form of a sensor belt around respondent's chest. The instructions were for the respondents to practice slow and deep breathing at about 10 breaths per minute for at least 40 minutes per week with each session lasting for at least 10 minutes.

Device-guided breathing (DGB), such as breathing exercises, is recommended as an effective nonpharmacological treatment for hypertension. DGB guides the respondents to breathe 14 times/minute. This study was independent. The DGB results were a significant decrease in systolic and diastolic blood pressure(Staffileno et al., 2018).

There was also a study that confirmed that for every $3.6 \mathrm{mmHg}$ reduction of the mean $\mathrm{BP}$, the relative risk of total cardiovascular events, stroke, coronary events, cardiovascular deaths and total deaths were $0.86,0.72,0.91,0.75$, and 0.78 times, respectively, out of a $2.4 \mathrm{~mm} \mathrm{Hg}$ reduction. These results confirm that a reduction in $\mathrm{BP}$ is important for cardiovascular patients(Zou et al., 2017).

When viewed regarding a history of smoking, there were 8 smoker respondents, 5 respondents who had decreased blood pressure, 2 of them with increased blood pressure and 1 respondent had a constant blood pressure. 


\section{R. FITRIYAH ET AL.}

For the respondents who did not have a smoking history, making up a total of 22 respondents, there were 14 respondents who had decreased blood pressure, 5 respondents whose blood pressure was constant and 3 respondents who had an increased blood pressure.

The tar in cigarettes is a hydrocarbon substance that is sticky and irritates the lungs, thereby increasing the production of mucus in the lungs as a result. Cigarette smokers have difficulty breathing because the airways into the lungs are blocked[11]. After the deep breath relaxation was performed on the respondents with a history of smoking, it decreased their blood pressure less than respondents who did not have a history of smoking. This is due to the accumulation of secretions in the lungs of people who smoke so then the deep breathing relaxation cannot be carried out optimally.

In addition, the researchers argue that 3of the respondents who did not have a history of smoking still had an increased blood pressure. This is because the respondents had a history of experiencing problems. Someone who has a problem is likely to cause an increase in blood pressure caused by an increase in the peripheral vascular resistance and cardiac output and due to the release of the hormone epinephrine (adrenaline) and norepinephrine (noradrenaline). This causes the blood vessels to constrict.

\section{CONCLUSION}

Before implementing the Deep Breathing Relaxation, most of the respondents had hypertension stage 1 . After implementing the Deep Breath Relaxation, most of respondents had a decrease in blood pressure (categorized as hypertension stage 1 through to normal tension). There was one respondent with hypertension stage 2 after implementing the deep breathing relaxation. $\mathrm{He}$ was categorized in hypertension stage 2 . There were differences in the blood pressure before and after implementing the Deep Breath Relaxation.

\section{REFERENCES}

Andarmoyo, S. (2012). Kebutuhan Dasar Manusia (Oksigenasi). Yogyakarta: Graha Ilmu.

Armstrong, C. (2014). Practice Guidelines JNC 8 Guidelines for the Management of Hypertension. American Family Physician, 90(7), 503-504. https://doi.org/10.1002/hipo.22742

Bai, Z., Chang, J., Chen, C., Li, P., Yang, K., \& Chi, I. (2015). Investigating the effect of transcendental meditation on blood pressure: A systematic review and meta-analysis. Journal of Human Hypertension, 29(11), 653-662. https://doi.org/10.1038/jhh.2015.6

Cernes, R., \& Zimlichman, R. (2015). RESPeRATE: The role of paced breathing in hypertension treatment. Journal of the American Society of Hypertension, $9(1)$, 38-47. https://doi.org/10.1016/j.jash.2014.10.002

Du, J., Zhang, D., Yin, Y., Zhang, X., Li, J., Liu, D., ... Chen, W. (2016). The Personality and Psychological Stress Predict Major Adverse Cardiovascular Events in Patients With Coronary Heart Disease After Percutaneous Coronary Intervention for Five Years. Medicine, 95(15), e3364. https://doi.org/10.1097/MD.000000000000336 4

Elliot W.J. (2004). Graded blood pressure reduction in hypertensive outpatients associated with use of a device to assist with slow breathing. Clin Hypertens, 6, 553-561.

Ettehad D. (2016). Blood pressure lowering for prevention of cardiovascular disease and death: a systematic review and meta-analysis. Lancet, 387, 957-967.

Jones CU. (2010). An inspiratory load enhances the anti-hypertensive effects of home-based trainingwith slow breathing: a randomized trial. J. Phys, 56, 179-186.

Joseph C.N. (2005). Slow breathing improves arterial baroreflex sensitivity and decreases blood pressure in essential hypertension. Hypertension, 46, 714-718.

Mahtani, K. R., Beinortas, T., Bauza, K., \& Nunan, D. (2016). Device-Guided Breathing for Hypertension: a Summary Evidence Review. Current Hypertension Reports, 18(4). https://doi.org/10.1007/s11906-016-0631-z

Mills, K. (2016). Global disparities of hypertension prevalence and control. Circulation, 134, 441-450.

Misra, S., Smith, J., Wareg, N., Hodges, K., Gandhi, M., \& McElroy, J. A. (2018). Take a deep breath: A randomized control trial of Pranayama breathing on uncontrolled hypertension. Advances in Integrative Medicine. https://doi.org/10.1016/j.aimed.2018.08.002

NICE. (2011). Hypertension: the clinical management of primary hypertension in adults: update of clinical guidelines 18 and 34. London: Royal College of Physicians.

Park, S.-H., \& Han, K. S. (2017). Blood Pressure Response to Meditation and Yoga: A Systematic Review and Meta-Analysis. The Journal of Alternative and Complementary Medicine, 23(9), 685-695. https://doi.org/10.1089/acm.2016.0234

Posadzki, P., Cramer, H., Kuzdzal, A., Lee, M. S., \& Ernst, E. (2014). Yoga for hypertension: A systematic review of randomized clinical trials. Complementary Therapies in Medicine, 22(3), 511522. https://doi.org/10.1016/j.ctim.2014.03.009

RI, K. K. (2018). Riskesdas.

Sangthong B. (2016). Breathing training for older patients with controlled isolated systolic hypertension. Med. Sci. Sports Exerc, 28, 147-158.

Satiti, A. (2011). Strategi Rahasia Berhenti Merokok. Yogyakarta: Datamedia.

Staffileno, B. A., Tangney, C. C., \& Fogg, L. (2018). Favorable Outcomes Using an eHealth Approach to Promote Physical Activity and Nutrition among 
Young African American Women. Journal of Cardiovascular Nursing, 33(1), 62-71. https://doi.org/10.1097/JCN.000000000000040 9

Triyanto, E. (2014). Pelayanan Keperawatan Bagi Penderita Hypertensi Secara Terpadu. Yogyakarta: Graha Ilmu.

Ublosakka-Jones, C., Tongdee, P., Pachirat, O., \& Jones, D. A. (2018). Slow loaded breathing training improves blood pressure, lung capacity and arm exercise endurance for older people with treated and stable isolated systolic hypertension. Experimental Gerontology, 108(March), 48-53. https://doi.org/10.1016/j.exger.2018.03.023
Wan R. (2014). Evidence that BDNF regulates heart rate by a mechanism involving increased brainstem parasympathetic neuron excitability. $J$ Neurochem, 129, 573-580.

WHO (World Health Organization). (2019). Raised Blood Pressure.

Zou, Y., Zhao, X., Hou, Y. Y., Liu, T., Wu, Q., Huang, Y. H., \& Wang, X. H. (2017). Meta-Analysis of Effects of Voluntary Slow Breathing Exercises for Control of Heart Rate and Blood Pressure in Patients With Cardiovascular Diseases. American Journal of Cardiology, 120(1), 148-153. https://doi.org/10.1016/j.amjcard.2017.03.247 